https://doi.org/10.17816/ecogen17293-100

\title{
PROTECTIVE EFFECT OF EXTRACTS OF TEUCRIUM POLIUM AND RUMEX CRISPUS AGAINST CYCLOPHOSPHAMIDE-INDUCED GENOTOXIC DAMAGE IN HUMAN LYMPHOCYTES
}

\author{
(C) S. Yuksel ${ }^{1}$, S.K. Sezer ${ }^{1}$, E.L. Kurtoglu' ${ }^{2}$, H.G. Bag ${ }^{1}$ \\ ${ }^{1}$ Inonu University, Malatya, Turkey; \\ ${ }^{2}$ Lokman Hekim University, Ankara, Turkey; \\ For citation: Yuksel S, Sezer SK, Kurtoglu EL, Bag HG. \\ Protective effect of extracts of Teucrium polium and Rumex crispus against \\ cyclophosphamide-induced genotoxic damage in human lymphocytes. \\ Ecological genetics. 2019;17(2):93-100. https://doi.org/10.17816/ecogen17293-100.
}

Teucrium polium (T. polium) and Rumex crispus (R. crispus) are plant species that grow widely in Anatolia and are thought to have healing effects for many diseases. In this study plant extracts are suggested as alternative agents in repairing cellular damage by using sister chromatid exchange (SCE), micronucleus (MN), mitotic index (MI), replication index (RI) and nuclear abnormalities (NAs), against the genotoxicity of cyclophosphamide (CP) in the human lymphocyte cells. 8 experimental groups were formed in the study. The cell culture medium was supplemented with $0.16 \mu \mathrm{g} / \mathrm{ml} \mathrm{CP}$ and the cells were treated with 50 , 100 and $250 \mu \mathrm{M}$ T. polium and R. crispus extracts in the presence and absence of CP. As a result, CP significantly decreased MI frequency while increasing SCE, MN and NAs frequencies in cells. $100 \mu \mathrm{M}$ T. polium plus CP decreased SCEs when compared with CP alone. In addition, MN frequency was significantly decreased in $100 \mu \mathrm{M}$ T. polium plus CP and $250 \mu \mathrm{M}$ R. crispus plus $\mathrm{CP}$ combine groups. Our results suggest that these plant extracts are not genetically damaging and have improving effects at these doses.

Seywords: Teucrium polium; Rumex crispus; cyclophosphamide; genotoxicity; human lymphocytes.

\section{INTRODUCTION}

The most important source of natural medicines used in traditional treatment methods is the plants. Turkey, in terms of medicinal and aromatic plants is one of the world's richest countries. Many of the plants have phytochemical, antioxidant and flavonoid properties. At present, plant extracts are suggested as alternative agents in improving cellular and genetic damage [1-4].

Teucrium polium (T. polium) and Rumex crispus (R. crispus) are plant species that are thought to have healing effects for many diseases among the common population in Anatolia [5]. Teucrium species are of the lamincea family, with more than 340 species. Northwest Asia and the Mediterranean region have been used by the public for 2000 years for treatment of diabetes, convulsion and gastrointestinal inflammation [6-8]. The results of Milosevic-Djordjevic et al. [9] who found that polyphenolic contents of $T$. polium by HPLC showed phenolic acid (gallic, vanillic, caffeic, chlorogenic, p-coumaric, sinapic) and flavonoids (catechin, rutin, myricetin, luteolin, quercetin and apigenin). Teucrium species have been reported to be able to repair DNA damage by stimulating deteoxification enzymes and have antioxidant, anticancer, hepatoprotective, hypolipidemic, hypoglycemic and antimicrobial effects [6, 10, 11].

Rumex is of the Poligonaceae family and show spread in Western and Northern Asia and Europe. Rumex species have been reported to have antioxidant and antimicrobial properties [12, 13]. R. crispus root, flowers, leaves and stems has been used for the treatment of pain, edema, hemorrhage, helminths, wound, internal bleeding and vascular diseases and dermatolosis in Asian medicine [14]. Pharmaceutical ability of $R$. crispus inhibits proliferation and induces apoptosis of cancer cells to scavenge free radicals, to suppress microbial growth have been recently studied [15, 16].

Cyclophosphamide (CP) that we used in this study as positive control, an alkylating chemotherapeutic agent, is widely used clinically as a chemo-therapeutic and immunosuppressant agent due to DNA binding ability, causing chromosome and chromatid breaks, sister union and chromatid exchanges. These single- and double-strand breaks are subsequently converted in to chromosome fragments and finally to chromosomal abnormalities, micronuclei $(\mathrm{MN})$ or sister chromatid exchange (SCE) after one cell division $[17,18]$. SCE refers to the interchange of DNA between replication products. $\mathrm{MN}$ is formed during the metaphase/anaphase transition of mitosis through various mechanisms. Frequencies of nuclear abnormalities (NAs) other than micronuclei, such as binucleates (BN), picnosis $(\mathrm{PK})$, karyorrhexis (KR) and karyolysis (KL) indicate very late stage in cell death process [19]. The frequency of SCE and MN has been used extensively for cytogenetic examination of peripheral lymphocytes in determining the mutagenic effects of drugs and xsenobiotics. These measures are indicators of exposure to genotoxic chemicals 
and markers of genome instability and cell proliferation status.

Medicinal plants have been traditionally used in the treatment of various diseases without knowing the effects on human cells and genetic materials. It is considered to be less toxic than synthetic counterparts due to the natural rich contents of plant extracts [1]. But many studies have shown that plant extracts used in traditional therapy may be potentially toxic and mutagenic. Plant extracts can be potentially toxic, mutagenic and carcinogenic depending on the concentration and duration of use $[1,20]$. There are many studies on the genotoxic or antigenotoxic effects of other species of Teucrium. But nowadays, no data on the induction of SCE, MN and cell cycle kinetics by $T$. polium and $R$. crispus extracts at different concentrations is published. For this reason, we tested the extracts of $T$. polium and $R$. crispus against the CP induced genotoxicity in the human lymphocyte cultures. We investigated also whether the various concentrations of these herbal medicines are possible genotoxic/cytotoxic potentials according to the different endpoints of genotoxicity: SCE, MN, NAs, cell growth kinetics such as MI and RI.

\section{MATERIALS AND METHODS}

\subsection{Chemicals}

Cyclophosphamide (CAS No. 6055-19-2), 5-Bromo-2deoxyuridine (CAS No. 59-14-3) and colchicine (CAS No. 477-30-5) were purchased from Sigma Chemicals. Peripheral Blood Karyotyping Medium (01-201-1B) was purchased from Biological Industries. Giemsa solution from Merck, India.

\subsection{Plant material}

In May-June 2017, aerial parts of T. Polium and R. crispus were collected from natural populations in east and south east Anatolia. The herbalist was identified with the help of the local administration and the plants were identified and taxonomically grouped at Pharmacy Faculty of Inonu University, Malatya, Turkey. The collected plant material was air-dried in darkness at ambient temperature for a short period of time. The dried plant materials was cut up and stored in dark colored containers as needed for the experiment.

\subsection{Plant extraction}

In this study, we prepared crude extracts of $T$. polium and $R$. crispus leaves according to traditional usage, as traditional medicinal plants are generally used as crude extracts. T. polium and R. crispus samples were extracted with methanol because of less carsinogenic that of other solvents and a wide range of phyto-chemical compounds are brought out by methanol easily. The dried aerial parts of $10 \mathrm{gr} T$. polium and $R$. crispus leaves were taken for methanolic extract. The methanolic extract was macerated $24 \mathrm{~h}$ with $100 \mathrm{ml}$ of solvent. The maceration was repeated 3 times. The extracts were filtered through a paper filter
(Whatman no. 1) and then evaporated to dryness under vacuum using rotary evaporator. The extracts were stored in sterile sample bottles. Sterile sample bottles were used as extract storage.

\subsection{Experimental protocols}

Peripheral blood was collected by venipuncture from two male and two female healthy, non-smokers donors aged 20-25 years. Eight experimental groups were formed in the study. Blood samples were added to $5 \mathrm{ml}$ chromosome medium B. For a group, the cells treated with $0.16 \mu \mathrm{g} / \mathrm{ml} \mathrm{CP}$ as positive control.

Methanolic extract of both $T$. polium and R. crispus in same three concentrations (50, 100 and $250 \mu \mathrm{M}$ ) were added seperately and in combination with $\mathrm{CP}$ treatmented to lymphocyte cultures $72 \mathrm{~h}$ before beginning of incubation. These nontoxic concentrations of extracts were determined with a prestudy on the cytotoxicity on the top concentration that resulted in approximately $50 \%\left(\mathrm{LD}_{50}\right)$ reduction in $\mathrm{MI}(250 \mu \mathrm{M})$. An untreated control was also established for each experiment.

\subsubsection{SCE assay}

Briefly $0.5 \mathrm{ml}$ of heparinized whole blood samples from donors were added to $5 \mathrm{ml}$ Chromosome Medium B supplemented with $10 \mu \mathrm{g} / \mathrm{ml} \mathrm{BrdUrd}$. Then the culture tubes were incubated at $37{ }^{\circ} \mathrm{C}$ for $72 \mathrm{~h}$. followed by $0.06 \mu \mathrm{g} / \mathrm{ml}$ colchicine treatment $1 \mathrm{~h}$ before culture termination to arrest mitoses. The lymphocytes were hypotonically treated in $0.075 \mathrm{M} \mathrm{KCl}$ and fixed in methanol: acetic acide $(3: 1)$. The staining of air-dried slides were modified fluorescence plus Giemsa method [21]. The slides were irradiated with $30 \mathrm{~W}, 254 \mathrm{~nm}$ UV lamp at $15 \mathrm{~cm}$ distance in Sorensen buffer, then incubated with $1 \times \mathrm{SSC}$ at $60{ }^{\circ} \mathrm{C}$ for 45-60 min and stained with 5\% Giemsa prepared with Sorensen buffer. The slides were coded before scoring. In order to score SCE, 25 second-division metaphases were analyzed for each donor at 1000x magnification using Olympus BH2 oil immersion lens and the frequency of SCE per cell was recorded.

2.4.2. In vitro cytokinesis-block micronucleus (MN) test and nuclear abnormalities (NAs) assay

For the analysis of $\mathrm{MN}, 0.5 \mathrm{ml}$ of fresh heparinized blood was used to establish cultures. The cells were treated with 50, 100 and $250 \mu \mathrm{M}$ of $T$. polium and R. crispus extracts for $72 \mathrm{~h}$ at $37{ }^{\circ} \mathrm{C}$. Cytochalasin B $(6 \mu \mathrm{g} / \mathrm{ml})$ was added to the cultures $44 \mathrm{~h}$ after the beginning of incubation to block cytokinesis. The cells were collected by centrifugation. The cells treated with cold hypotonic solution $(0,56 \% \mathrm{KCL})$ and three times in methanol: acetic acide $(3: 1)$ for fixation. Then the cells were dropped onto slides and stained with $5 \%$ Giemsa.

For MN analysis, Olympus BH2 light microscope using 400x magnification on coded slides was used. In all subjects, 1000 binucleated lymphocytes were scored from each donor (4000 binucleated cells were scored per concentration). De- 
generative nuclear changes, such as BN (binucleated cells), PK (condensation of nuclear material), KL (dissolution of nucleus) and KR (nuclear disintegration) were analyzed in the binucleated lymphocytes at MN slides. $M N$ and other nuclear abnormalities were classified according to Tolbert et al. [19] MNs must satisfy the following conditions: a) consist of nuclear material; b) be completely separated from the parent nucleus; c) be less than $1 / 3$ of the diameter of associated nuclei; d) be smooth, oval- or round-shaped; e) be on the same plane of focus and f) be of the same color, texture and refraction as the main nucleus.

\subsubsection{Cell cycle kinetics}

The MI explains the effects of the chemicals on G2 stage of cell cycle and the RI reflects the effects of the chemicals on $\mathrm{S}$ and $\mathrm{G}_{2}$ stages of the cycles. Cells undergoing, first $\left(M_{1}\right)$, second $\left(M_{2}\right)$ and third $\left(M_{3}\right)$ metaphase divisions were detected with BrdU-Harlequin technique for differential staining of metaphase chromosomes. The RI was calculated according to the following formula:

$$
\mathrm{RI}=\left(1 \cdot M_{1}\right)+\left(2 \cdot M_{2}\right)+\left(3 \cdot M_{3}\right) / \text { total scored cells. }
$$

$M_{1}, M_{2}$, and $M_{3}$ are the first, second and third mitosis during cell culture period.
A total 100 cells per donor were scored for the determination of RI. For the MI was also determined by scoring 3000 cells from each donor.

\subsection{Statistical analysis}

Normality of data was evaluated by Shapiro-Wilk test. Normally distributed data was summarized by mean \pm standard deviation. Homogeneity of variances of groups was tested by Levene test. Since the variances of groups found to be heterogeneous, Welch test and Tamhane's T2 post-hoc method was used for comparison of the groups. When the groups have observations lower than 10, median, minimum and maximum values was used as descriptive statistics. Comparisons due to these variables were performed by KruskalWallis test and Conover pairwise comparison method. In all analysis significance level was considered as 0,05.

\section{RESULTS}

Comparison of the frequency of SCE, MI and RI different concentration treatments within groups can be seen in Table 1. In this experiment, CP significantly decreased RI and MI frequency while increasing SCE, on healthy human lymphocytes. T. polium and R. crispus extracts did

Table 1

Comparison of SCE, MI and RI frequencies at different treatment concentrations in cultured human lymphocytes treated with $T$. polium, R. crispus and cyclophosphamide

\begin{tabular}{|c|c|c|c|c|}
\hline \multicolumn{2}{|r|}{ Groups } & $\operatorname{SCE}($ Mean \pm SD $)$ & MI Median (Min-Max) & RI Median (Min-Max) \\
\hline A & Control & $6.79 \pm 2.15$ B, F, G, H, K, L, M, N & $3.33(3.17-3.99)^{\text {B, E, F, G, H, L, N }}$ & $2.45(2.32-2.51)^{\mathrm{B}, \mathrm{F}, \mathrm{G}, \mathrm{H}, \mathrm{L}, \mathrm{M}, \mathrm{N}}$ \\
\hline B & Cyclophosphamide (CP) & $42.74 \pm 10.33^{\text {A, C, D, E, G, I, J, K }}$ & $1.75(1.72-1.86)^{\mathrm{A}, \mathrm{C}, \mathrm{D}, \mathrm{E}, \mathrm{G}, \mathrm{I}, \mathrm{J}, \mathrm{K}, \mathrm{M}}$ & $1.59(1.54-1.78)^{\mathrm{A}, \mathrm{C}, \mathrm{D}, \mathrm{E}, \mathrm{I}, \mathrm{J}, \mathrm{K}, \mathrm{L}, \mathrm{M}}$ \\
\hline \multicolumn{5}{|c|}{ T.polium } \\
\hline $\mathrm{C}$ & $50 \mu M$ & $6.68 \pm 1.77^{\mathrm{B}, \mathrm{F}}$ & $3.49(2.93-3.68)^{\text {B, E, F }}$ & $2.38(2.26-2.58)^{\mathrm{B}, \mathrm{F}}$ \\
\hline $\mathrm{D}$ & $100 \mu M$ & $8.53 \pm 1.98^{\mathrm{B}, \mathrm{G}}$ & $3.39(2.96-3.48)^{\text {B, E, G }}$ & $2.32(2.17-2.45)^{\mathrm{B}, \mathrm{G}}$ \\
\hline $\mathrm{E}$ & $250 \mu \mathrm{M}$ & $9.53 \pm 2.76^{\text {В, H }}$ & $2.88(2.85-2.93)^{\text {A, B, C, D }}$ & $2.23(2.09-2.41)^{\mathrm{B}, \mathrm{H}}$ \\
\hline \multicolumn{5}{|c|}{ T. polium + CP } \\
\hline $\mathrm{F}$ & $50 \mu M$ & $35.58 \pm 4.31^{\mathrm{A}, \mathrm{C}, \mathrm{G}}$ & $2.54(2.39-2.66)^{\mathrm{A}, \mathrm{C}}$ & $1.94(1.58-2.25)^{\mathrm{A}, \mathrm{C}}$ \\
\hline $\mathrm{G}$ & $100 \mu \mathrm{M}$ & $27.58 \pm 7.80^{\text {A, B, D, F }}$ & $2.58(2.06-3.05)^{\mathrm{A}, \mathrm{B}, \mathrm{D}}$ & $1.92(1.64-2.15)^{\mathrm{A}, \mathrm{D}}$ \\
\hline $\mathrm{H}$ & $250 \mu \mathrm{M}$ & $33.21 \pm 4.57^{\mathrm{A}, \mathrm{E}}$ & $2.42(2.18-2.71)^{\mathrm{A}}$ & $1.94(1.71-2.14)^{\mathrm{A}, \mathrm{E}}$ \\
\hline \multicolumn{5}{|c|}{ R. crispus } \\
\hline $\mathrm{I}$ & $50 \mu M$ & $7.63 \pm 2.50^{\mathrm{B}, \mathrm{L}}$ & $3.34(2.82-3.53)^{\mathrm{B}, \mathrm{L}}$ & $2.34(2.25-2.44)^{\mathrm{B}, \mathrm{L}}$ \\
\hline $\mathrm{J}$ & $100 \mu \mathrm{M}$ & $8.53 \pm 2.46^{\mathrm{B}, M}$ & $3.1(2.74-3.48)^{\mathrm{B}}$ & $2.37(1.97-2.57)^{\mathrm{B}, M}$ \\
\hline K & $250 \mu M$ & $9.84 \pm 2.54$ A, B, M, N & $3.08(2.96-3.62)^{\mathrm{B}, \mathrm{N}}$ & $2.26(1.97-2.57)^{\mathrm{B}}$ \\
\hline \multicolumn{5}{|c|}{ R. crispus + CP } \\
\hline $\mathrm{L}$ & $50 \mu M$ & $35.32 \pm 6.00^{\mathrm{A}, \mathrm{I}}$ & $2.38(1.85-3.02)^{\mathrm{A}, \mathrm{I}}$ & $2.06(1.77-2.26)^{\mathrm{A}, \mathrm{B}, \mathrm{I}}$ \\
\hline$M$ & $100 \mu M$ & $33.53 \pm 4.99 \mathrm{~A}, \mathrm{~J}, \mathrm{~K}$ & $2.65(1.85-3.17)^{\mathrm{B}}$ & $2.02(1.87-2.27)^{\text {A, B, J }}$ \\
\hline $\mathrm{N}$ & $250 \mu M$ & $34.32 \pm 4.82^{\mathrm{A}, \mathrm{K}}$ & $2.36(1.65-3.12)^{\mathrm{A}, \mathrm{K}}$ & $1.86(1.67-2.29)^{\mathrm{A}}$ \\
\hline & $p$, value & $<0.001$ & $<0.001$ & 0.001 \\
\hline
\end{tabular}

Note. The letters in the column symbolize the groups for pairwise comparisons. Superscript letters represent the statistically significant difference between groups. A total 50 cells were scored for the SCE assay; 200 cells were scored for the RI and 3000 cells were scored for the MI. 
Table 2

Comparison of $M N$ frequency and nuclear abnormalities at different treatment concentrations in cultured human lymphocytes treated with $T$. polium, $R$. crispus and cyclophosphamide

\begin{tabular}{|c|c|c|c|c|c|c|c|}
\hline & Groups & $\begin{array}{l}\text { MN Median } \\
(\text { Min-Max })\end{array}$ & $\begin{array}{c}\text { BN cells } \\
\text { Median } \\
\text { (Min-Max })\end{array}$ & $\begin{array}{c}\text { Mn cells } \\
\text { Median } \\
(\text { Min-Max })\end{array}$ & $\begin{array}{c}\text { Pyknosis } \\
\text { Median } \\
\text { (Min-Max) }\end{array}$ & $\begin{array}{c}\text { Karyolysis } \\
\text { Median } \\
\text { (Min-Max) }\end{array}$ & $\begin{array}{c}\text { Karyorxhesis } \\
\text { Median } \\
\text { (Min-Max) }\end{array}$ \\
\hline A & Control & $\begin{array}{c}4 \\
(2-6)^{\mathrm{B}, \mathrm{G}, \mathrm{H}, \mathrm{L}, \mathrm{M}, \mathrm{N}} \\
\end{array}$ & $\begin{array}{c}21 \\
(18-25)^{\mathrm{F}, \mathrm{G}, \mathrm{H}, \mathrm{L}} \\
\end{array}$ & $\begin{array}{c}979 \\
(975-982)^{\mathrm{F}, \mathrm{G}, \mathrm{H}, \mathrm{L}} \\
\end{array}$ & $\begin{array}{c}2 \\
(0-4)^{\mathrm{B}} \\
\end{array}$ & $\begin{array}{c}1.5 \\
(0-4)^{\mathrm{B}, \mathrm{G}, \mathrm{H}} \\
\end{array}$ & $\begin{array}{c}0.5 \\
(0-1)^{\mathrm{B}, \mathrm{F}, \mathrm{G}, \mathrm{H}, \mathrm{L}} \\
\end{array}$ \\
\hline B & $\begin{array}{l}\text { Cyclophos- } \\
\text { phamide (CP) }\end{array}$ & $\begin{array}{c}15 \\
(11-16)^{\mathrm{A}, \mathrm{C}, \mathrm{D}, \mathrm{E}, \mathrm{F},} \\
\mathrm{G}, \mathrm{I}, \mathrm{J}, \mathrm{K}, \mathrm{N}\end{array}$ & $\begin{array}{c}22.5 \\
(10-37)^{\mathrm{C,F}}\end{array}$ & $\begin{array}{c}977.5 \\
(963-990)^{\mathrm{C}, \mathrm{F}}\end{array}$ & $\begin{array}{c}4.5 \\
(3-6)^{A, C, D, E, F, I,} \\
J, K, M, N\end{array}$ & $\begin{array}{c}4 \\
(2-5)^{A, C, D, I, J, K, M}\end{array}$ & $\begin{array}{c}2.5 \\
(1-5)^{\mathrm{A}, \mathrm{C}, \mathrm{K}, \mathrm{M}}\end{array}$ \\
\hline \multicolumn{8}{|c|}{ T. polium } \\
\hline C & $50 \mu M$ & $\begin{array}{c}4 \\
(2-5)^{\mathrm{B}} \\
\end{array}$ & $\begin{array}{c}15 \\
(12-21)^{\mathrm{B}, \mathrm{D}, \mathrm{E}, \mathrm{F}} \\
\end{array}$ & $\begin{array}{c}985 \\
(979-988)^{\text {B, D, E,F }} \\
\end{array}$ & $\begin{array}{c}2 \\
(1-3)^{\mathrm{B}} \\
\end{array}$ & $\begin{array}{c}1.5 \\
(0-4)^{\mathrm{B}}\end{array}$ & $\begin{array}{c}1 \\
(0-2)^{\mathrm{B}, \mathrm{F}}\end{array}$ \\
\hline $\mathrm{D}$ & $100 \mu \mathrm{M}$ & $\begin{array}{c}4.5 \\
(2-9)^{\mathrm{B}}\end{array}$ & $\begin{array}{c}24 \\
(16-31)^{\mathrm{C}}\end{array}$ & $\begin{array}{c}976 \\
(969-984)^{\mathrm{C}}\end{array}$ & $\begin{array}{c}0.5 \\
(0-2)^{\mathrm{B}, \mathrm{G}}\end{array}$ & $\begin{array}{c}1 \\
(1-1)^{\mathrm{B}, \mathrm{G}}\end{array}$ & $\begin{array}{c}1 \\
(0-3)^{G}\end{array}$ \\
\hline E & $250 \mu M$ & $\begin{array}{c}5 \\
(2-8)^{\mathrm{B}, \mathrm{H}}\end{array}$ & $\begin{array}{c}26 \\
(24-29)^{\mathrm{C}, \mathrm{K}}\end{array}$ & $\begin{array}{c}974 \\
(971-976)^{\mathrm{C}, \mathrm{K}}\end{array}$ & $\begin{array}{c}2 \\
(1-3)^{\mathrm{B}}\end{array}$ & $\begin{array}{c}2 \\
(1-3)^{\mathrm{H}}\end{array}$ & $\begin{array}{c}1.5 \\
(1-2)^{\mathrm{H}}\end{array}$ \\
\hline \multicolumn{8}{|c|}{ T. polium + CP } \\
\hline $\mathrm{F}$ & $50 \mu M$ & $\begin{array}{c}4 \\
(3-7)^{\mathrm{B}, \mathrm{G}, \mathrm{H}, \mathrm{L}}\end{array}$ & $\begin{array}{c}30.0 \\
(28-32)^{\mathrm{A}, \mathrm{B}, \mathrm{C}}\end{array}$ & $\begin{array}{c}970 \\
(968-972)^{\mathrm{A}, \mathrm{B}, \mathrm{C}}\end{array}$ & $\begin{array}{c}2 \\
(2-3)^{\mathrm{B}}\end{array}$ & $\begin{array}{c}3 \\
(1-5) \\
\end{array}$ & $\begin{array}{c}3 \\
(2-5)^{\mathrm{A}, \mathrm{C}}\end{array}$ \\
\hline G & $100 \mu M$ & $\begin{array}{c}7.5 \\
(6-9)^{A, B, F} \\
\end{array}$ & $\begin{array}{c}28.5 \\
(27-31)^{\mathrm{A}} \\
\end{array}$ & $\begin{array}{c}971.5 \\
(969-973)^{\mathrm{A}} \\
\end{array}$ & $\begin{array}{c}2 \\
(2-4)^{\mathrm{D}} \\
\end{array}$ & $\begin{array}{c}4 \\
(3-7)^{A, D}, M \\
\end{array}$ & $\begin{array}{c}3 \\
(2-3)^{A, D}, M \\
\end{array}$ \\
\hline $\mathrm{H}$ & $250 \mu \mathrm{M}$ & $\begin{array}{c}10.0 \\
(8-11)^{\mathrm{A}, \mathrm{E}, \mathrm{F}}\end{array}$ & $\begin{array}{c}29.5 \\
(26-34)^{\mathrm{A}, \mathrm{N}}\end{array}$ & $\begin{array}{c}970.5 \\
(966-974)^{\mathrm{A}, \mathrm{N}}\end{array}$ & $\begin{array}{c}2.5 \\
(2-3)\end{array}$ & $\begin{array}{c}4 \\
(3-6)^{\mathrm{A}, \mathrm{E}, \mathrm{N}}\end{array}$ & $\begin{array}{c}4.5 \\
(4-5)^{\mathrm{A}, \mathrm{E}, \mathrm{N}}\end{array}$ \\
\hline \multicolumn{8}{|c|}{ R.crispus } \\
\hline I & $50 \mu M$ & $\begin{array}{c}5.5 \\
(4-8)^{\mathrm{B}} \\
\end{array}$ & $\begin{array}{c}24 \\
(21-26)^{\mathrm{L}} \\
\end{array}$ & $\begin{array}{c}976 \\
(974-979)^{\mathrm{L}}\end{array}$ & $\begin{array}{c}2 \\
(1-2)^{\mathrm{B}}\end{array}$ & $\begin{array}{c}1 \\
(0-1)^{\mathrm{B}, \mathrm{L}} \\
\end{array}$ & $\begin{array}{c}1 \\
(0-3) \\
\end{array}$ \\
\hline $\mathrm{J}$ & $100 \mu \mathrm{M}$ & $\begin{array}{c}6.5 \\
(4-9)^{\mathrm{B}} \\
\end{array}$ & $\begin{array}{c}24.5 \\
(23-26) \\
\end{array}$ & $\begin{array}{c}975.5 \\
(974-977) \\
\end{array}$ & $\begin{array}{c}1 \\
(0-2)^{\mathrm{B}, M} \\
\end{array}$ & $\begin{array}{c}1 \\
(0-2)^{\mathrm{B}} \\
\end{array}$ & $\begin{array}{c}1.5 \\
(1-2) \\
\end{array}$ \\
\hline K & $250 \mu M$ & $\begin{array}{c}5.5 \\
(4-6)^{\mathrm{B}}\end{array}$ & $\begin{array}{c}18.5 \\
(15-22)^{\mathrm{E}}\end{array}$ & $\begin{array}{c}981.5 \\
(978-985)^{\mathrm{E}}\end{array}$ & $\begin{array}{c}1 \\
(1-2)^{\mathrm{B}}\end{array}$ & $\begin{array}{c}1.5 \\
(1-3)^{\mathrm{B}}\end{array}$ & $\begin{array}{c}1 \\
(0-1)^{\mathrm{B}}\end{array}$ \\
\hline \multicolumn{8}{|c|}{ R. crispus + CP } \\
\hline $\mathrm{L}$ & $50 \mu M$ & $\begin{array}{c}8 \\
(7-9)^{\mathrm{A}, \mathrm{F}}\end{array}$ & $\begin{array}{c}29.5 \\
(28-32)^{\mathrm{A}, \mathrm{I}, \mathrm{N}}\end{array}$ & $\begin{array}{c}970.5 \\
(968-972)^{\mathrm{A}, \mathrm{N}, \mathrm{I}}\end{array}$ & $\begin{array}{c}2.5 \\
(2-3)\end{array}$ & $\begin{array}{c}2.5 \\
(2-3)^{\mathrm{I}}\end{array}$ & $\begin{array}{c}1.5 \\
(1-3)^{\mathrm{A}}\end{array}$ \\
\hline$M$ & $100 \mu \mathrm{M}$ & $\begin{array}{c}9 \\
(6-11)^{\mathrm{A}}\end{array}$ & $\begin{array}{c}25.5 \\
(25-27)^{\mathrm{N}}\end{array}$ & $\begin{array}{c}974.5 \\
(973-975)^{\mathrm{N}}\end{array}$ & $\begin{array}{c}2 \\
(2-3)^{\mathrm{B}, \mathrm{J}}\end{array}$ & $\begin{array}{c}1.5 \\
(1-2)^{\mathrm{B}, \mathrm{G}}\end{array}$ & $\begin{array}{c}1 \\
(0-2)^{\mathrm{B}, \mathrm{G}}\end{array}$ \\
\hline $\mathrm{N}$ & $250 \mu \mathrm{M}$ & $\begin{array}{c}7.5 \\
(6-9)^{\mathrm{A}, \mathrm{B}} \\
\end{array}$ & $\begin{array}{c}19 \\
(16-22)^{\mathrm{H}, \mathrm{L}, \mathrm{M}} \\
\end{array}$ & $\begin{array}{c}981 \\
(978-984)^{\mathrm{H}, \mathrm{L}, M} \\
\end{array}$ & $2(1-2)^{B}$ & $\begin{array}{c}2 \\
(0-5)^{\mathrm{H}} \\
\end{array}$ & $\begin{array}{c}1.5 \\
(1-2)^{\mathrm{H}}\end{array}$ \\
\hline & $p$, value & 0.001 & 0.002 & 0.002 & 0.022 & 0.007 & 0.003 \\
\hline
\end{tabular}

Note. The letters in the column symbolize the groups for pairwise comparisons. Superscript letters represent the statistically significant difference between groups. A total 50 cells were scored for the SCE assay; 200 cells were scored for the RI and 3000 cells were scored for the MI.

not alter the mean SCEs (except the $250 \mu \mathrm{M}$ concentration of $R$. crispus), MIs (except the $250 \mu \mathrm{M}$ concentration of $T$. polium) and RIs for all concentrations compared to untreated control. However, T. polium and R. crispus extracts and $\mathrm{CP}$ as a mixture showed a synergistic effect on increasing the SCEs, except the $100 \mu \mathrm{M}$ concentration of $T$. polium plus CP. In addition, in the $100 \mu \mathrm{M}$ con- centration of $T$. polium and $R$. crispus as a mixture with $\mathrm{CP}, \mathrm{MI}$ frequencies were higher than $\mathrm{CP}$ alone treatment group. Similarly the $50 \mu M$ and $100 \mu M$ concentration of $R$. crispus combined groups with $\mathrm{CP}$ showed protective effect for the RI (Table 1).

Table 2 gives the MN frequency and nuclear abnormalities of differences between control and treatment 
groups. When we compared the $M N$ and degenerative nuclear alterations between different concentrations within groups, statistically significant differences were found. MN frequency was significantly decreased in $\mathrm{CP}$ group and all combine groups with CP (except $50 \mu \mathrm{M}$ T. polium plus $\mathrm{CP}$ ). In addition $\mathrm{MN}$ frequency of the $100 \mu \mathrm{M} \mathrm{T}$. polium and $250 \mu \mathrm{M}$ R. crispus combine groups as a mixture decreased when compared to positive control CP. When we compared of the frequency of $\mathrm{BN}, \mathrm{KL}$, and $\mathrm{KR}$ in different concentration treatments within groups it was found that; among the all concentrations of plant extracts nucleus abnormality parameters were in normal values, combine groups of $50 \mu \mathrm{M}$ and $100 \mu \mathrm{M}$ concentration of $R$. crispus showed decreasing effect at this pathological structures.

\section{DISCUSSION}

A large number of authors have suggested the use of medicinal plants as antimutagenic agents in the prevention of genotoxic effects of different chemotherapeutic agents [22-24]. However, as far as we know, determination of the protective effects of $T$. polium and $R$. crispus extracts combined with any known mutagenic substance is not studied. The molecular mechanisms behind of these plants genomic stability, cancer or anti-cancer role are still not clearly understood. For this reason, we were designed this study to determine the safety and genotoxic/antigenotoxic outcome data of this herbs in cultured human peripheral blood lymphocytes as determined by SCI, MI, $\mathrm{RI}, \mathrm{MN}$ and NAs.

We found that SCE and MN were significantly increased in CP group. By these results, the previously declared clastogenic and genotoxic effect of CP has been confirmed Chemotherapeutic agents such as $\mathrm{CP}$ are toxic and many are mutagenic. Cyclophosphamide-mediated genotoxicity either occur induction of microtubule damages or DNA reactive intermediates or endogenous mutagenic agents [23, 25]. Genotoxic substances induce damage in cells through interaction with the DNA and can result, including single- and double-strand breaks, cross-links between DNA bases and proteins, and chemical additions to the DNA. The occurrence of genomic damage, if left unrepaired, may result in the formation of DNA adducts, chromosome/chromatid breaks, or aneuploidy and is associated with the formation of micronucleus $(\mathrm{MN})$, sister chromatid exchange (SCE), and overall genomic instability $[17,26]$. This may be the reason for SCE and $\mathrm{MN}$ formation in lymphocyte cells after CP treatment. $\mathrm{MN}$ is indicator of genomic instability and cytogenetic damage in dividing cells. Various experimental systems were used to study the genotoxical potential of CP and have been reported to induce structural chromosomal aberrations, SCEs and MN frequency in cultured cells $[18,27]$.
In this study the observed high incidence of $\mathrm{MN}$, SCE formations and nucleus anomalies in the lymphocyte cells confirmed the clastogenic potential of CP. In contrast, possibly due to their antioxidant effect, $T$. polium and $R$. crispus extracts produced protective and anti-genotoxic effects on DNA damage. T. polium and R. crispus extracts did not show any genotoxic effect for examined parameters at all concentrations. In the combine groups, plant extracts shown partial protective effects. For SCE moderate dose of $T$. polium and for MN moderate dose of $T$. polium and the highest dose of $R$. crispus decreased the genotoxic effect of CP. The results of our study clearly indicate protective properties of methanolic extracts of $T$. polium and $R$. crispus against the genotoxic effect of $\mathrm{CP}$ in a dosedependent manner.

Quercetin-3-O- $\beta$-D-glucuronopyranoside (QGC) that has anti-oxidative, antitumor and anti-inflammatory effects in vivo, the most important flavonoid glucoside extracted from Teucrium and Rumex species $[7,9,28,29]$. The antimutagenic and anticancerogenic effects of $T$. polium were tested in the mammalian system and this plant extract was reported to decrease the SCE and chromosomal abnormalities [24]. Tepe and his colleagues in 2010 have examined antioxidant and DNA damage protection activities of $T$. polium, and reported that T. polium is rich in phenolic and flavonoid contents and can be used as an alternative to a synthetic antioxidant source [30]. In another study that methanolic extracts of $T$. polium were applied in combination with anticancer drugs (cisplatin, vincristine, vinblastine and, doxorubicin) to the cancer cell line showed that for cancer therapy the extract was potentially safe and effective as a chemosensitizer agent [10]. For cancer therapy, to determine the potential anticancer effects of $T$. polium, all these in vitro studies showed the essentiality of the animal experimentation and clinical trials. T. polium contains five phenolic acids and six flavonoids, the most important therapeutic polyphenolic compounds [9, 31]. In our study, moderate and high concentrations of plant extractions showed a protective effect for many genotoxicity tests. Numerous studies provide evidence for mutagenic/antimutagenic or prooxidant/antioxidant activities largely depend on the concentration used of medical plants $[8,9,31,32]$.

Studies on anticancer, antioxidant and free radical scavenging properties of $R$. crispus have been extensively studied in vitro models $[12,13,16,33]$ but there is no information on the potential genotoxic or antigenotoxic effects of this herb. Shiwani and colleagues in 2012 investigated methanolic root extracts of $R$. crispus free radical scavenging properties and DNA and protein protection abilities. As a result, they observed that R.crispus inhibited DNA damage in HT29 cells. However, in order to know the exact components of $R$. crispus responsible for these biological activities, they indicated that advanced 
technologies should be used for detailed chemical analyzes [16]. Hot water extracts of both the seeds and leaves of $R$. crispus $\mathrm{L}$. were reported to have the highest antioxidant activity Yıldırım et al. [12].

In this study the sensitivity of the $M N$ is increased by recording degenerative nuclear alterations, such as $\mathrm{PK}, \mathrm{KR}, \mathrm{KL}$ and $\mathrm{BN}$ cells in addition to the MN. To determine possible cytotoxic/anticytotoxic effects of CP alone and also with combine treatment of these plant extracts, as well as for controls, we analyzed the MI, RI and NAs for each experimental concentration. The results indicated that $\mathrm{CP}$ caused significant departures of MI, RI and increase of NAs values with reference to the control. The data of cell cycle kinetics parameters of plant extracts were not significant compared to the control. In addition, at different concentrations of plant extracts mixture with CP treated groups, had cytoprotective effect on MI, RI and NAs frequencies. The nuclear abnormalities reflect progressive chromosomal and genomic instability. Structural nuclear anomalies or losing nuclear materials cause nucleus anomalies such as binucleate cells, PK, KR, KL or MN [19]. In our study especially moderate $R$. crispus concentration with $\mathrm{CP}$ decreased the NAs frequency against $\mathrm{CP}$ cytotoxicity.

These are the situations limiting this study. The protective effects of methanolic extracts of $T$. polium and $R$. crispus against $\mathrm{CP}$-induced genetic damage in cultured human peripheral blood lymphocytes could be attributed to the limited concentration treatment and short duration of this study. It is known that, long-term use of such plants may be harmful due to their cytotoxic and genotoxic content.

\section{CONCLUSION}

Recently, plant extracts are used to be as alternative chemo-preventive agents of medical treatments and has become widespread throughout the world but the molecular mechanisms behind of these plants genotoxic or antigenotoxic are still not clearly understood. As far as we know, this is the first study on the protective effects of methanolic extracts of $T$. polium and $R$. crispus against $\mathrm{CP}$-induced genetic damage in cultured human peripheral blood lymphocytes. Together with the results obtained, we can say that the $\mathrm{CP}$ is quite efficient in inducing genetic damage and cell growth kinetics and extracts of $T$. polium and $R$. crispus extracts are genetically damaging improving effects at the these experimental dosages. It is anticipated that this outcome will be supported by similar or more advanced studies.

\section{Acknowledgements}

We thank Dr. Turan Arabaci from Pharmacy Faculty of Inonu University for plant identifications and extractions.
Author contributions: SY performed the research and wrote the manuscript. SY, SKS and ELK performed the cell culture and analyzed the cytogenetic parameters. HGB assisted in statistical analyzes. Author SY declares that she has no conflict of interest. Author SKS declares that she has no conflict of interest. Author ELK declares that she has no conflict of interest. Author HGB declares that she has no conflict of interest.

Ethical approval: This article does not contain any studies with human participants or animals performed by any of the authors.

Funding: This study was done with laboratory facilities and not supported by any foundation.

\section{REFERENCES}

1. Celik TA. Potential Genotoxic and Cytotoxic Effects of Plant Extracts. IntechOpen. 2012. https://doi. org/10.5772/28488.

2. Ozkan G, Kamiloglu S, Ozdal T, et al. Potential Use of Turkish Medicinal Plants in the Treatment of Various Diseases. Molecules. 2016;21(3):257. https://doi. org/10.3390/molecules2 1030257.

3. Gontijo VS, Dos Santos MH, Viegas C, Jr. Biological and Chemical Aspects of Natural Biflavonoids from Plants: A Brief Review. Mini Rev Med Chem. 2017;17(10):834-862. https://doi.org/10.2174/1389 557517666161104130026 .

4. Bozkurt-Guzel C, Serbetci T, Kultur S. Cytotoxic activities of some Turkish medicinal plants against HeLa cells in vitro. Indian J Traditional Knowledge. 2018;17(1):43-49.

5. Dinç M, Doğu S, Bilgili B, Duran A. Comparative anatomical and micromorphological studies on Teucrium creticum and Teucrium orientale var. orientale ( $T$. sect. Teucrium, Lamiaceae). Nord J Bot. 2009;27(3):251 -256. https://doi.org/10.1111/j.1756-1051.2008.00323.x.

6. Hasani P, Yasa N, Vosough-Ghanbari S, et al. In vivo antioxidant potential of Teucrium polium, as compared to a-tocopherol. Acta Pharm. 2007;57(1):123-129. https://doi.org/10.2478/v10007-007-0010-z.

7. Sharififar F, Dehghn-Nudeh G, Mirtajaldini M. Major flavonoids with antioxidant activity from Teucrium polium L. Food Chemistry. 2009;112(4):885-888. https://doi.org/10.1016/j.foodchem.2008.06.064.

8. Bahramikia S, Yazdanparast R. Phytochemistry and medicinal properties of Teucrium polium L. (Lamiaceae). Phytother Res. 2012;26(11):1581-1593. https://doi.org/10.1002/ptr.4617.

9. Milosevic-Djordjevic O, Radovic Jakovljevic M, Markovic A, et al. Polyphenolic contents of Teucrium polium L. and Teucrium scordium L. associated with their protective effects against MMC-induced chromosomal damage in cultured human peripheral blood lymphocytes. Turk J Biol. 2018;42(2):152-162. https://doi. org/10.3906/biy-1707-36. 
10. Rajabalian S. Methanolic extract of Teucrium polium L. potentiates the cytotoxic and apoptotic effects of anticancer drugs of vincristine, vinblastine and doxorubicin against a panel of cancerous cell lines. Exp Oncol. 2008;30(2):133-138.

11. Sghaier MB, Ismail MB, Bouhlel I, et al. Leaf extracts from Teucrium ramosissimum protect against DNA damage in human lymphoblast cell K562 and enhance antioxidant, antigenotoxic and antiproliferative activity. Environ Toxicol Pharmacol. 2016;44:44-52. https://doi.org/10.1016/j. etap.2016.04.006.

12. Yildırım A, Mavi A, Kara AA. Determination of Antioxidant and Antimicrobial Activities of Rumex crispus L. Extracts. J Agric Food Chem. 2001;49(8):4083-4089. https://doi.org/10.1021/jf0103572.

13. Idris OA, Wintola OA, Afolayan AJ. Phytochemical and antioxidant activities of Rumex crispus L. in treatment of gastrointestinal helminths in Eastern Cape Province, South Africa. Asian Pac J Trop Biomed. 2017;7(12):1071-1078. https://doi.org/10.1016/j. apjtb.2017.10.008.

14. Shim KS, Lee B, Ma JY. Water extract of Rumex crispus prevents bone loss by inhibiting osteoclastogenesis and inducing osteoblast mineralization. BMC Complement Altern Med. 2017;17(1):483. https:// doi.org/10.1186/s12906-017-1986-7.

15. Coruh I, Gormez A, Ercisli S, Sengul M. Total Phenolic Content, Antioxidant, and Antibacterial Activity of Rumex crispus Grown Wild in Turkey. Pharm Biol. 2008;46(9):634-638. https://doi. org/10.1080/13880200802182240.

16. Shiwani S, Singh NK, Wang MH. Carbohydrase inhibition and anti-cancerous and free radical scavenging properties along with DNA and protein protection ability of methanolic root extracts of Rumex crispus. Nutr Res Pract. 2012;6(5):389-395. https://doi. org/10.4162/nrp.2012.6.5.389.

17. Uren N, Yuksel S, Onal Y. Genotoxic effects of sulfur dioxide in human lymphocytes. Toxicol Ind Health. 2014;30(4):311-315. https://doi. org/10.1177/0748233712457441.

18. Yuksel S, Tasdemir S, Korkmaz S. Protective effect of thymoquinone against cyclophosphamideinduced genotoxic damage in human lymphocytes. Bratisl Lek Listy. 2017;118(4):208-211. https://doi. org/10.4149/BLL_2017_041.

19. Tolbert PE, Shy CM, Allen JW. Micronuclei and other nuclear anomalies in buccal smears: methods development. Mutat Res. 1992;271(1):69-77. https:// doi.org/10.1016/0165-1161(92)90033-i.

20. AL-Dulaimi, DW, Faisal SF, Baharetha HM, et al. Cytogenetic an experimental monitoring test for plant extracts. IOSR J Pharm Biol Sci. 2017;12(1):100-105.
21. Speit G, Haupter S. On the mechanism of differential Giemsa staining of bromodeoxyuridine-substituted chromosomes. Hum Genet. 1985;70(2). https://doi. org/10.1007/bf00273070.

22. Yuksel S, Yesilada E, Gulbay G, et al. Protective effect of myricetin against estradiol-17 $\beta$-induced genotoxic damage in human lymphocytes. Fresenius Environmental Bulletin. 2012;21(4):1022-1026.

23. Zulkipli IN, David SR, Rajabalaya R, Idris A. Medicinal Plants: A Potential Source of Compounds for Targeting Cell Division. Drug Target Insights. 2015;9:9-19. https://doi.org/10.4137/DTI.S24946.

24. Rahmouni F, Saoudi M, Amri N, et al. Protective effect of Teucrium polium on carbon tetrachloride induced genotoxicity and oxidative stress in rats. Arch Physiol Biochem. 2018;124(1):1-9. https://doi.org/ 10.1080/13813455.2017.1347795.

25. Zhang J, Tian Q, Zhou S-F. Clinical Pharmacology of Cyclophosphamide and Ifosfamide. Curr Drug Ther. 2006;1(1):55-84. https://doi. org/10.2174/157488506775268515.

26. Kurtoglu EL, Yuksel S. Genotoxic effects of tacrolimus on human lymphocyte cells. Russian Journal of Genetics. 2012;48(6):651-655. https://doi. org/10.1134/s1022795412050134.

27. Kocaman AY, Istifli ES, Buyukleyla $M$, et al. In vitro evaluation of the protective effects of 4 -thujanol against mitomycin-C and cyclophosphamide-induced genotoxic damage in human peripheral lymphocytes. Toxicol Ind Health. 2013;29(1):23-37. https://doi. org/10.1177/0748233712436640.

28. Cho EJ, Um SI, Han JH, et al. The cytoprotective effect of Rumex Aquaticus Herba extract against hydrogen peroxide-induced oxidative stress in AGS cells. Arch Pharm Res. 2016;39(12):1739-1747. https://doi.org/10.1007/s12272-016-0863-0.

29. Wang Q, Wang Y, Xing Y, et al. Physcion 8-O-beta-glucopyranoside induces apoptosis, suppresses invasion and inhibits epithelial to mesenchymal transition of hepatocellular carcinoma HepG2 cells. Biomed Pharmacother. 2016;83:372-380. https:// doi.org/10.1016/j.biopha.2016.06.045.

30. Tepe B, Degerli S, Arslan S, et al. Determination of chemical profile, antioxidant, DNA damage protection and antiamoebic activities of Teucrium polium and Stachys iberica. Fitoterapia. 2011;82(2):237-246. https://doi.org/10.1016/j. fitote.2010.10.006.

31. Ozer Z, Kiliç T, Çarikçi S, et al. Investigation of phenolic compounds and antioxidant activity of Teucrium polium L. decoction and infusion. J BAUN Inst Sci Technol. 2018;20(1):212-218. https://doi. org/10.25092/baunfbed.370594.

32. Ljubuncic P, Dakwar S, Portnaya I, et al. Aqueous extracts of Teucrium polium possess remarkable 
antioxidant activity in vitro. Evid Based Complement Alternat Med. 2006;3(3):329-338. https://doi. org/10.1093/ecam/nel028.
33. Wegiera M, Smolarz HD, Bogucka-Kocka A. Rumex L. species induce apoptosis in 1301, EOL-1 and H-9 cell lines. Acta Pol Pharm. 2012;69(3):487-499.

(8) Information about the authors

Sengul Yuksel - Medical Faculty, Department of Medical Biology \& Genetics,

Inonu University, Malatya, Turkey. E-mail: sengul.yuksel@inonu.edu.tr.

Selcen Korkmaz Sezer - Medical Faculty, Department of Medical Biology \& Genetics,

Inonu University, Malatya, Turkey. E-mail: selcenkorkmaz@hotmail.com.

Elcin Latife Kurtoglu - Medical Faculty, Department of Medical Biology,

Lokman Hekim University, Ankara, Turkey. E-mail: elcinkurtoglu@hotmail.com.

Harika Gozukara Bag - Medical Faculty, Department of Biostatistics and Medical Informatics,

Inonu University, Malatya, Turkey. E-mail: harika.gozukara@inonu.edu.tr. 